\title{
METAL LEVELS IN COMMON SEAWEEDS FROM SUEZ BAY
}

\author{
Islam M. El-Manawy-1, Wagdy M. El-Sarraf ${ }^{-2}$, and Fikry A. Mourad ${ }^{-2}$ \\ ${ }^{-1}$ Botany Dept., Fac. Sci., Suez Canal Uni, ${ }^{-2}$ National Institute of Oceanography \\ and Fisheries
}

\begin{abstract}
Metal levels $(\mathrm{Cd}, \mathrm{Co}, \mathrm{Cr}, \mathrm{Cu}, \mathrm{Mn}, \mathrm{Fe}, \mathrm{Pb}, \mathrm{Ni}$ and $\mathrm{Zn})$ were determined in water and 24 species of seaweeds at 8 sites on Suez Bay close to the industrial and urban zone, from March 1998 through February 1999. The seaweeds of the Suez Bay contribute competently for elimination of trace metals from the water. The levels of metal in seawater were between $0.105 \mathrm{ppb}$ for chromium and $20.76 \mathrm{ppb}$ for zinc. In seaweed species, the levels were between $1.93 \mathrm{ppm}$ for chromium and $1528.89 \mathrm{ppm}$ for iron. Many species have high capacity for absorption of certain metals, making them good bioremediators. At the forefront, Cladophoropsis zollingeri (Chlorophyta) accumulated $\mathrm{Cr}, \mathrm{Fe}$, and $\mathrm{Mn}$ at 70, 112, and 306 times their levels in seawater. For $\mathrm{Cd}, \mathrm{Co}$, and $\mathrm{Pb}$, calcareous algae such as Jania rubens, Halimeda tuna, and Galaxaura oblongata are good bioremediators. They accumulated 29, 32, and 34 times the levels measured in seawater.
\end{abstract}

Keywords: bioremediators, Suez Bay, trace metals, seaweeds, metal pollution.

\section{Introduction}

Although trace metals at low concentrations are essential to life, at high concentrations they may become hazardous. The imposition of stricter environmental regulations increases the demand for more competitive, effective and economically treatment methods for removal and recovery of toxic metals from industrial effluents which is a scientific challenge.

Aquatic plants provide a viable alternative for metals remediation if proper disposal of spent plants can be employed (Ray and Ray, 2002). Aquatic macrophytes are known to remove metals by surface adsorption and/or absorption and incorporate them into their own system or store them in a bound form (Rai et al., 1995; Espinoza-Quinones et al., 2005). Since early 1970s several works have demonstrated that seaweeds can be used to partially strip trace metal in the marine waters (Folsom et al., 1963; Folsom and Young, 1965; Phillips, 1977, 1993, Langston, 1986; Malea and Haritonidis, 2000; Garrison, 2004).

Suez Bay (Fig. 1) is surrounded by an industrial zone with three oil refineries, three power stations, fertilizer, steel and textile factories, which could be a source of many pollutants including trace elements. Navigation activities in Suez Canal, Port Tawfik and Adabyea harbors may also form another source of trace elements. The aim of this work was to investigate $\mathrm{Cd}, \mathrm{Co}, \mathrm{Cr}, \mathrm{Cu}, \mathrm{Mn}, \mathrm{Fe}$, 
$\mathrm{Pb}, \mathrm{Ni}$ and $\mathrm{Zn}$ meditation in Suez Bay seawater and evaluate the efficiency of its seaweeds in metal remediation.

\section{The study area:}

The Suez Bay (Fig.1) is located at the end of the Gulf of Suez between (Long. $32^{\circ} 28^{`} \& 32^{\circ} 34^{\backslash} \mathrm{E}$ ) and (Lat. $29^{\circ} 54^{\prime} \& 29^{\circ} 57^{`} \mathrm{~N}$ ) with an area of 77.13 $\mathrm{Km}^{2}$. Its depth is $10 \mathrm{~m}$ in average but there is a navigation channel of $12 \mathrm{~m}$ depth connecting the bay with the Gulf of Suez and Suez Canal. The current direction is generally anti-clockwise, from north to south. Selection of sampling sites was based on the water current direction and sources of pollution in Suez Bay. Site (I) is located at Eion Mousa and has no land-based pollution sources.

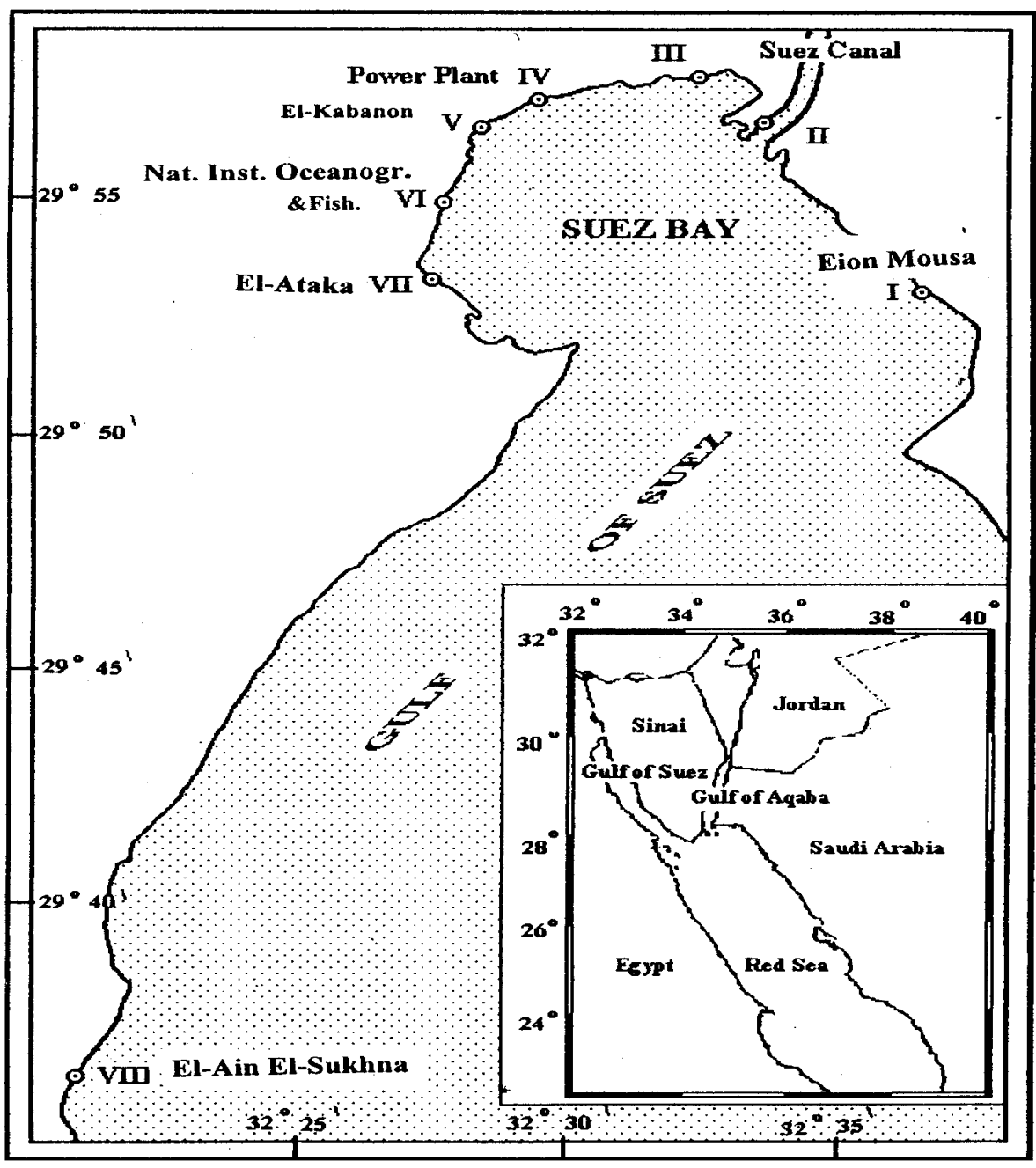

Figure (1): The investigated sites at Suez Bay. Inset: Red Sea. 
Site (II) is located Port Tawfik, the southern entrance of the Suez Canal and is affected by the pollutants of navigation activities. Site (III) is located near a shipbuilding and maintenance workshops. Site (IV) is located in the middle of the bay and is affected by the effluent discharges from Suez Petroleum Company, Thermal Power plant and untreated sewage of El-Mamal dwelling zone. Site (V) is located at El-Kabanon zone and is affected by untreated sewage from the Suez City and effluents from El-Nasr Fertilizers Company. Site (VI) is directly affected by industrial soluble wastes from textile and palm oil factories, dust from a steel factory, and a sewage treatment plant output $2 \mathrm{Km}$ off shore. Site (VII) is located close to El-Ataka fishing harbor and could be affected by the antifouling paints. Site (VIII) is located at Ein-Elsukhna, $60 \mathrm{Km}$ south of Suez, where the shore has rocks, dead corals and sandy pools, all are covered with oil deposits.

\section{Materials and Methods}

Seaweed samples were monthly collected from the intertidal zone from March 1998 through February 1999. Identification of the species was carried out using standard references (e.g., Aleem, 1993; Børgesen, 1957; Dawson, 1962; Jaasund, 1977). For analysis, algal samples were thoroughly washed with distilled water and stored in plastic pages at $-20^{\circ} \mathrm{C}$. The frozen algae were thawed, washed with distilled water, allowed to dry and powdered in a PVC mortar. Two liters of surface water were collected in colorless polyethylene bottles, acidified and filtered through a pre-weighed 45um GF. The dissolved trace metals were measured in seaweeds and seawater using the method described by Brook et al. (1967) and a flame photometer AAS (Perkin Elmer 301), and expressed in ppm and ppb, respectively.

\section{Results and Discussion \\ Trace metals in seawater}

Table (1) shows the annual mean and standard deviation of the dissolved nine metals measured in seawater at different sites. Trace metal levels were in the sequence of $\mathrm{Zn}>\mathrm{Fe}>\mathrm{Pb}>\mathrm{Ni}>\mathrm{Cu}>\mathrm{Co}>\mathrm{Cd}>\mathrm{Mn}>\mathrm{Cr}$. The higher annual mean level of zinc was $20.76 \mathrm{ppb}$ and the lower annual mean level of $\mathrm{Cr}$ was $0.105 \mathrm{ppb}$. Zinc levels in this study were very high as compared with previous work in Suez Bay and other areas of the world. Other elements were in comparable levels to those measured in non-polluted and may be lower than the quality standards in coastal waters (Harper, 1988; Hester and Harrison, 2000; Garrison, 2004).

Dissolved cadmium showed total annual mean of $0.272 \pm 0.178 \mathrm{ppb}$. The level at different sites was 0.217-0.339 ppb. Abdel-Azim (1996) and El-Moselhy et al. (1999) found dissolved cadmium of $0.26-0.87 \mathrm{ppb}$ in Suez Bay water. This

level is lower than the quality standards $(2.50 \mathrm{ppb} \mathrm{Cd})$ recommended by the 


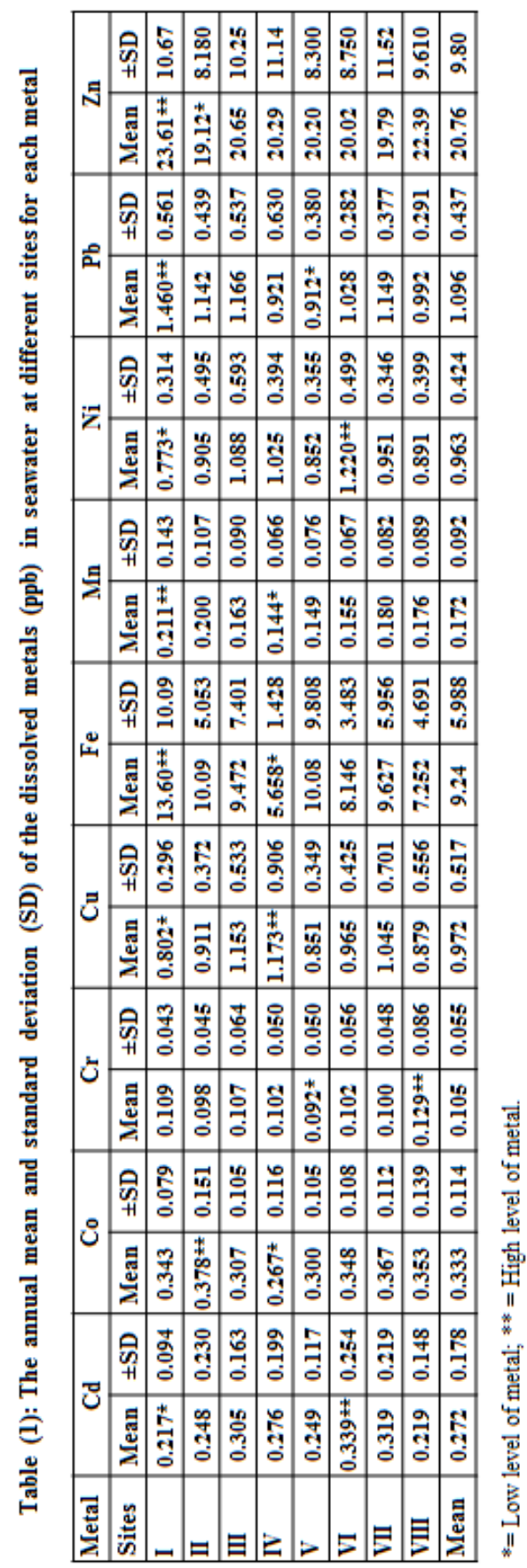


European Community for dissolved metals in coastal waters (Harper, 1988).

Cadmium level in seawater depends mainly on the dissolved fraction (Dowidar and El-Nady, 1987).

Dissolved cobalt showed total annual mean of $0.33 \pm 0.11 \mathrm{ppb}$. The level at different sites was $0.267-0.378 \mathrm{ppb}$. Hamed (1996) found lower level of 0.10 $0.70 \mathrm{ppb}$, while EL-Moselhy et al. (1999) found 0.33 - $0.73 \mathrm{ppb}$ in Suez Bay water.

Dissolved chromium showed total annual mean of $0.11 \pm 0.06 \mathrm{ppb}$. The level at different sites was $0.092-0.129 \mathrm{ppb}$. The variation of chromium level may be related to plankton growth (Brewer, 1975) and bacterial decomposition of organic matter (Forstner and Wittmann, 1981). The chromium level in this study exceeded the standard limit in unpolluted seawater $(0.08 \mathrm{ppb} \mathrm{Cr}$, Cranston and Murray, 1978). Muse et al. (1999) found 0.04- $0.50 \mathrm{ppb}$ of dissolved $\mathrm{Cr}$ in south Atlantic, Argentina.

Dissolved cupper showed total annual mean of $0.972 \pm 0.517 \mathrm{ppb}$. The level at different sites was $0.802-1.173 \mathrm{ppb}$. El-Moselhy (1993) found a level of 0.71 - $5.50 \mathrm{ppb}$ in Suez Bay; later on the level was lowered to 1.13 - 2.62 (ELMoselhy et al., 1999). Variation in dissolved copper may be attributed to chelation by particulate organic matter and algal growth (Forstner and Wittmann, 1981). In non-polluted oceanic waters, cupper was measured at levels ranging from 0.02 to $3.00 \mathrm{ppb}$ (Goldberg, 1965; Preston et al., 1972; Boyale et al., 1977; Bruland and Frankie, 1983; Jaleel et al., 1993; Muse et al. (1999).

Iron is the most abundant element in the seawater and occurs mainly in a particulate phase as a result of the formation of Fe (III) in well-oxygenated seawater (Dowidar and El-Nady, 1987). Dissolved iron showed total annual mean of $9.24 \pm 5.988 \mathrm{ppb}$. The level at different sites was 5.658-13.600 ppb. The higher value (13.600 ppb) was found at site I and may be resulted from the corrosion of submerged military wrecks. The lower value was measured at site IV may be, as suggested by Forstner and Wittmann (1981), due to chelation of dissolved ions by particulate organic matter from the untreated sewage. Sites II and VI showed high iron levels as they receive dust waste of a steel factory. The present dissolved level of iron is comparable to that measured in many areas of the world (e. g. Magnusson and Rasmussum, 1982; Jickells and Knap, 1984; Emara et al., 1995).

Dissolved manganese showed total annual mean of $0.0 .17 \pm 0.09 \mathrm{ppb}$. The level at different sites was $0.144-0.211 \mathrm{ppb}$. The levels are the same with those measured by Goldberg (1965) and Hamed (1996) in Suez Bay water. Level was high at sites I and II. The terrestrial source from local mountains and desert may be the source especially during the windy months ( $\mathrm{Li}$ and Chin, 1997). The consumption by algae may be the reason for low level at other sites. Manganese is essential element in glucose utilization of living organisms (Forstner and Wittmann, 1981). 
Dissolved nickel showed total annual mean of $0.963 \pm 0.424 \mathrm{ppb}$. The level at different sites was $0.773-1.220 \mathrm{ppb}$. Sites III, IV and VI showed the higher levels measured in the seawater. These sites are nearby Nasr Petroleum Company, sewage effluents, and shipbuilding. Dean et al. (1972) and Forstner and Wittmann (1981) stated that steel works and oil industry are major sources for nickel. Nickel level in this study is less than the standard limit $(2.00 \mathrm{ppb}$; Goldberg, 1965; Waldichut, 1974).

Dissolved lead showed total annual mean of $1.096 \pm 0.437 \mathrm{ppb}$. The level at different sites was $0.912-1.460 \mathrm{ppb}$. The higher level several sites may be, as mentioned by Jickells and Knap (1984) due to atmospheric fallout from oil refineries in the region. In all conditions, lead levels were much lower than the standard limit $(25.00 \mathrm{ppb})$ recommended by the European Community for dissolved metals in coastal waters (Harper, 1988). Lead forms poorly soluble salts that have low mobilization (Forstner and Wittmann, 1981)

Zinc is one of the most abundant essential elements, approximately 100 times as copper (Forstner and Wittmann, 1981). Dissolved zinc showed total annual mean of $20.760 \pm 9.80 \mathrm{ppb}$. The level at different sites was $19.12-23.61$ ppb. The anti-fouling paints at Adabyea and Ataka Harbours with the Suez Company for fertilizers are the major source of zinc. Zinc levels in this study were high as compared with previous work in Suez Bay and other areas of the world. In the Suez Bay, El-Moselhy (1993) found 1.30-7.71 ppb dissolved zinc; El-Moselhy et al. (1999) found 4.30-12.12 ppb. Goldberg (1965) reported average concentration of $10 \mathrm{ppb}$ of zinc in water from World Ocean. Magnusson and Rasmussen (1982) found $0.80 \mathrm{ppb}$ of dissolved zinc in the Danish Coastal water. Jickells and Knap (1984) found dissolved zinc of $0.30 \mathrm{ppb}$ in seawater from Bermuda.

\section{Trace metals in seaweeds}

Table (2) shows the mean levels of the nine metals measured in 24 species, 8 Chlorophyta, 9 Phaeophyta, and 7 Rhodophyta. The total average in all species was in the sequence of $\mathrm{Fe}>\mathrm{Zn}>\mathrm{Mn}>\mathrm{Pb}>\mathrm{Ni}>\mathrm{Cd}>\mathrm{Co}>\mathrm{Cu}>\mathrm{Cr}$. This sequence disagreed with that recorded in water.

The level of cadmium in studied Chlorophyta seaweed was varied between 1.93 ppm in Bryopsis plumose and 10.93 ppm in Halimeda tuna. This level is 9 to 32 times its level in seawater. The higher level of cadmium in Halimeda tuna may be referred to its calcareous structure. Other non calcareous Chlorophyta are lower than Halimeda and this is found to be in accordance with the result given by Shiber (1980) from Lebanon, Jaleel et al. (1993) from Arabian Sea, El-Sarraf (1995) from Alexandria, and Muse et al. (1999) from Argantina. Cadmium levels in Phaeophyta were lower than Chlorophyta. In the former group, the level was between $4.22 \mathrm{ppm}$ in Padina pavonica and $2.172 \mathrm{ppm}$ in Stypopodium zonale. 
Table (2): Mean level of trace elements (ppm dry wt.) in the selected seaweeds for each metal

\begin{tabular}{|c|c|c|c|c|c|c|c|c|c|}
\hline Species & Cd & Co & $\mathrm{Cr}$ & $\mathbf{C u}$ & $\mathbf{F e}$ & Mn & $\mathrm{Ni}$ & $\mathbf{P b}$ & Zn \\
\hline \multicolumn{10}{|c|}{ Chlorophyta } \\
\hline \begin{tabular}{|l|} 
Bryopsis \\
plumosa
\end{tabular} & $1.93 *$ & 3.59 & 4.04 & 6.51 & 1147.06 & 23.76 & 7.12 & 26.38 & 48.21 \\
\hline $\begin{array}{l}\text { Caulerpa } \\
\text { racemosa. }\end{array}$ & 3.91 & 4.09 & 2.09 & 3.60 & 891.89 & 25.10 & 6.58 & 19.64 & 35.96 \\
\hline $\begin{array}{l}\text { Chaetomorpha } \\
\text { linum }\end{array}$ & 4.41 & 4.41 & 3.29 & 4.70 & 876.55 & 23.30 & 7.10 & 24.43 & 52.90 \\
\hline $\begin{array}{l}\text { Cladophora } \\
\text { serica }\end{array}$ & 3.29 & 5.85 & 7.92 & $10.36 * *$ & 1343.04 & 42.32 & 11.97 & 31.70 & 65.95 \\
\hline \begin{tabular}{|l|} 
Cladophoropsis \\
zollingeri
\end{tabular} & 3.76 & 7.46 & $9.03 * *$ & 10.17 & $1528.89 * *$ & $64.65 * *$ & 12.73 & 37.29 & 49.67 \\
\hline $\begin{array}{l}\text { Enteromorpha } \\
\text { intestinalis }\end{array}$ & 3.05 & 4.67 & 4.98 & 8.41 & 1226.12 & 25.11 & 12.27 & 27.50 & 55.08 \\
\hline Halimeda tuna & $10.93 * *$ & 10.40 & 3.08 & 6.10 & 1163.10 & 29.47 & 13.98 & 43.27 & 37.13 \\
\hline Ulva lactuca & 3.23 & 3.61 & 2.17 & 7.16 & 689.42 & 19.61 & 8.79 & 31.86 & 38.94 \\
\hline \multicolumn{10}{|c|}{ Phaeophyta } \\
\hline \begin{tabular}{|l|}
$\begin{array}{l}\text { Colpomenia } \\
\text { sinuosa }\end{array}$ \\
\end{tabular} & 3.00 & 5.60 & 4.46 & 5.51 & 1236.83 & 43.05 & 9.45 & 28.82 & 22.50 \\
\hline \begin{tabular}{|l|} 
Cystoseira \\
myrica
\end{tabular} & 3.40 & 4.65 & 3.47 & 3.74 & 1150.09 & 37.45 & 7.30 & 17.69 & 36.50 \\
\hline \begin{tabular}{|l|} 
Dictyota \\
dichotoma
\end{tabular} & 3.67 & 4.55 & 3.47 & 6.66 & 1263.31 & 37.28 & 7.69 & 20.91 & 23.27 \\
\hline \begin{tabular}{|l} 
Giffordia \\
mitchellae
\end{tabular} & 2.50 & 5.14 & 3.87 & 5.29 & 1347.55 & 33.03 & 8.50 & 24.31 & 27.67 \\
\hline $\begin{array}{l}\text { Hydroclathrus } \\
\text { clathratus }\end{array}$ & 3.00 & 5.78 & 3.59 & 3.17 & 1439.46 & 61.55 & 9.35 & 23.04 & $70.52 * *$ \\
\hline $\begin{array}{l}\text { Padina } \\
\text { pavonica }\end{array}$ & 4.23 & 6.86 & 3.61 & 4.86 & 1113.66 & 62.04 & $16.65^{* * *}$ & 29.68 & 27.79 \\
\hline $\begin{array}{l}\text { Sargassum } \\
\text { latifolium }\end{array}$ & 2.72 & 3.81 & 1.95 & 3.72 & 773.81 & 24.24 & 6.28 & 20.30 & 20.31 \\
\hline \begin{tabular}{|l} 
Stypopodium \\
zonale
\end{tabular} & 2.17 & 5.08 & 3.90 & 9.04 & 1192.58 & 44.24 & 8.00 & 23.43 & 30.33 \\
\hline $\begin{array}{l}\text { Turbinaria } \\
\text { triquetra }\end{array}$ & 3.07 & $2.04 *$ & $0.14^{*}$ & $1.47 *$ & $185.59 *$ & $7.23 *$ & $3.63 *$ & $12.58 *$ & $12.46^{*}$ \\
\hline \multicolumn{10}{|c|}{ Rhodophyta } \\
\hline $\begin{array}{l}\text { Acanthophora } \\
\text { najadiformis }\end{array}$ & 3.10 & 5.06 & 2.57 & 7.05 & 1213.90 & 44.47 & 8.34 & 21.15 & 58.36 \\
\hline $\begin{array}{l}\text { Chondria } \\
\text { seticulosa }\end{array}$ & 2.81 & 6.37 & 5.34 & 5.54 & 1319.23 & 39.08 & 9.49 & 23.54 & 68.73 \\
\hline $\begin{array}{l}\text { Galaxaura } \\
\text { oblongata }\end{array}$ & 5.42 & $10.84 * *$ & 4.93 & 9.07 & 1083.60 & 58.95 & 14.50 & 40.93 & 47.09 \\
\hline \begin{tabular}{|l|} 
Hypnea \\
cornuta
\end{tabular} & 2.44 & 3.33 & 2.76 & 7.58 & 686.76 & 14.93 & 6.15 & 15.92 & 45.95 \\
\hline Jania rubens & 4.98 & 10.42 & 3.60 & 4.37 & 1254.22 & 56.28 & 13.41 & $50.25 * *$ & 41.30 \\
\hline $\begin{array}{l}\text { Laurencia } \\
\text { papillosa }\end{array}$ & 3.03 & 5.02 & 4.34 & 4.66 & 1080.77 & 48.00 & 11.08 & 23.79 & 44.72 \\
\hline $\begin{array}{l}\text { Liagora } \\
\text { farinosa }\end{array}$ & 5.18 & 10.00 & 4.27 & 4.85 & 1119.84 & 41.35 & 12.79 & 43.25 & 27.38 \\
\hline Total average & 3.72 & 5.78 & 3.87 & 5.98 & 1096.97 & 37.77 & 9.71 & 27.57 & 41.2 \\
\hline
\end{tabular}

$*=$ Low level of metal; $* *=$ High level of metal. 
Rhodophycean species displayed levels between $5.417 \mathrm{ppm}$ in Galaxaura and $2.44 \mathrm{ppm}$ in Hypnea. The calcareous structures of Galaxaura, Liagora, and Jania may increase their ability to accumulate cadmium than the other non calcareous species and there are in accordance with the measurement given by ElSarraf (1995) from Alexandria and Wahbeh (1985) from Gulf of Aqaba.

Cobalt is an essential element for living organisms (Moore, 1991). The level of cobalt in studied seaweed was varied between $2.04 \mathrm{ppm}$ in Turbinaria triquetra (Phaeophyta) and $10.84 \mathrm{ppm}$ in Galaxaura oblongata (Rhodophyta). This level is 8 to 29 times its level in seawater. Liagora farinose and Jania rubens (Rhodophyta) and Halimeda tuna (Chlorophyta) also accumulate $10 \mathrm{ppm}$ approx. All of these species with Galaxaura are calcareous algae, and this character may increase the efficiency of cobalt accumulation. Cladophoropsis zollingeri, Padina pavonica, and Chondria seticulosa were good remediators of cobalt as they accumulated 7.46, 6.86, $6.37 \mathrm{ppm}$, respectively. The present levels of cobalt are more or less in accordance with those recorded by Seanko et al. (1976) from Japan.

The level of chromium in studied seaweed was varied between $0.14 \mathrm{ppm}$ in Turbinaria triquetra (Phaeophyta) and $9.03 \mathrm{ppm}$ in Cladophoropsis zollingeri (Chlorophyta). This level is 2 to 70 times its level in seawater. Cladophora serica (Chlorophyta) and Chondria seticulosa (Rhodophyta) accumulated 7.92, 5.34 $\mathrm{ppm}$, respectively. Other algae showed concentration lower than $5 \mathrm{ppm}$. Seanko et al. (1976) recorded Cr levels between 3.5 and $23.4 \mathrm{ppm}$ in similar species from Japan, meanwhile Muse et al. (1995) found similar levels from Gulf of San Jorge, Argentina.

The level of cupper in studied seaweed was varied between $1.47 \mathrm{ppm}$ in Turbinaria triquetra (Phaeophyta) and $10.36 \mathrm{ppm}$ in Cladophora serica (Chlorophyta). This level is 2 to 9 times its level in seawater. Fourteen of the studied species contained 5-10 ppm of cupper (Table 2). Many literatures recorded cupper in levels that highly exceed the present values. In Gulf of Aqaba, Wahbeh (1985) found levels of 42.1, 48.1, 50, 55.3, $59.5 \mathrm{ppm}$ in Ulva lactuca, Liagora turneri, Laurancia obtuse, Halimeda tuna, and Galaxaura lapidescens, respectively. From Kuwait coast on the Arabian Gulf, Buo-Olayan and Subrahmanyam (1996) found 45, 150, 60-120, and 85-120 ppm in Cladophora ceolorix, Cladophoropsis sp., Enteromorpha sp., and Ulva lactuca, respectively. Cupper is the second most toxic metal after mercury. Cupper sulfate is used to control nuisance algae in freshwater. Even though, it is an essential micronutrient. Its toxicity is dependent on the ionic activity (the free $\mathrm{Cu}^{+2}$ ) and not the total salt. The lowest toxic $\mathrm{Cu}^{+2}$ concentration for sporophytes of Laminaria hyperborea was 3.3 times its concentration in the water (Zamuda and Sunda, 1982).

Iron is an essential element for plants especially for chlorophyll and oxidation-reduction reactions (Park and Plock, 1971). The level of iron in studied 
seaweed was varied between $185.59 \mathrm{ppm}$ in Turbinaria triquetra (Phaeophyta) and $1528.89 \mathrm{ppm}$ in Cladophoropsis zollingeri (Chlorophyta). This level is 33 to 112 times its level in seawater. Nineteen of the 24 studied species accumulated more than $1000 \mathrm{ppm}$ of cupper (Table 2), and many of which were either calcareous or fleshy. Sivalingam (1978) found very high iron levels of 4735.57117.6 ppm in many similar species of seaweeds, however almost other studies showed levels similar to this study (Agadi et al., 1978; Wahbeh, 1985; El-Sarraf, 1995; Malea et al., 1995; Buo-Olayan and Surahmanyam, 1996).

The level of manganese in studied seaweed was varied between $7.23 \mathrm{ppm}$ in Turbinaria triquetra (Phaeophyta) and $64.65 \mathrm{ppm}$ in Cladophoropsis zollingeri (Chlorophyta). This level is 50 to 306 times its level in seawater. Except Turbinaria, Hypnea and Ulva, other species contained prominent values over than $20 \mathrm{ppm}$ (Table 2). Agadi et al. (1978) found very high Mn levels of 2685.53, 111.25-1721.51, and $74.58 \mathrm{ppm}$ in Enteromorpha clathrata, Ulva spp. and Caulerpa sertutaroides from Goa coast, India. Buo-Olayan and Surahmanyam 1996, found similar Mn levels of 75 ppm in Cladophoropsis sp. and 55-71 ppm in Enteromorpha spp. but higher of 20-75 ppm in Ulva lactuca from Kuwait coast.

Nickel is a non-essential element for the living organisms. It is used as a catalyst in oil refineries. The level of nickel in studied seaweed was varied between $3.63 \mathrm{ppm}$ in Turbinaria triquetra and $16.65 \mathrm{ppm}$ in Padina pavonica, the two species from Phaeophyta. This level is 5 to 14 times its level in seawater. Cladophora serica, Cladophoropsis zollingeri,i Enteromorpha intestinalis, and Halimeda tuna from Chlorophyta accumulated 11.97, 12.73, 12.27, 13.98 ppm, respectively. Galaxaura oblongata, Jania rubens, Laurencia papillosa, and Liagora farinose from Rhodophyta accumulated 14.50, 13.41, 11.08, and 12.79 ppm, respectively. All species in this study showed Ni levels higher than the limit concentration (1 ppm) of the unpolluted seaweeds (Riley and Skirrow, 1965 and Tomlinson et al., 1980).

Lead is a non-essential for living organisms. It inhibited the respiration when corn (a terrestrial plant) was exposed to lead, but when inorganic phosphate was added, there was no inhibition. Lead appeared to bind with phosphate and precipitate (Koeppe and Miller, 1970). The chloroplast ultrastructure of the freshwater plant Ceratophyllum demersum was altered when exposed to various levels of lead and inorganic phosphate (Rebechini and Zegers, 1972). On the other hand, sedentary (benthic) algae have high capacity for absorption of lead with no alteration, making them good indicators for lead (Forstner and Wittmann, 1981). The level of lead in studied seaweed was varied between $12.58 \mathrm{ppm}$ in Turbinaria triquetra and $50.25 \mathrm{ppm}$ in Jania rubens (from calcareous Rhodophyta). This level is 14 to 34 times its level in seawater. Other calcareous algae also contained high levels; Halimeda tuna (43.27 ppm), Liagora farinose (43.25 ppm), and Galaxaura oblongata (40.93 ppm). 
Zinc is an essential element for plant life and participates in photosynthesis (Park and Plock, 1971). The level of zinc was varied between $12.46 \mathrm{ppm}$ in Turbinaria triquetra (Phaeophyta) and $70.52 \mathrm{ppm}$ in Hydroclathrus clathratus (Phaeophyta). The studied seaweeds had low ability to accumulate zinc. The present level is calculated as 0.7 to 3 times its level in seawater. From Kuwait coast, Buo-Olayan and Subrahmanyam (1996) found very high levels of 200, 425, and 192- 610 ppm in Cladophora, Enteromorpha, and Padina. Almost other studies showed levels similar to this study (Agadi et al., 1978; Wahbeh, 1985; El-Sarraf, 1995).

In conclusion, the benthic algae in Suez Bay contribute competently for elimination of trace metals from the water. Many species have high capacity for absorption of certain metals, making them good bioremediators. At the forefront, Cladophoropsis zollingeri (Chlorophyta) accumulated $\mathrm{Cr}, \mathrm{Fe}$, and $\mathrm{Mn}$ at 70, 112, and 306 times their levels in seawater. For $\mathrm{Cd}, \mathrm{Co}$, and $\mathrm{Pb}$, calcareous algae such as Jania rubens, Halimeda tuna, and Galaxaura oblongata are good bioremediators. They accumulated 29,32, and 34 times the levels in seawater.

\section{References}

Abdel-Azim, A. H. (1996). Lead dynamics in Suez Bay. M.Sc. Thesis, Fac. Sci., Helwan University.

Agadi, V. V.; Bhosle, N. B. and Untwale, A. G. (1978). Metal concentration in some seaweeds of Goa (India). Bot. Mar., 21: 147-250.

Aleem, A. A. (1993). The marine algae of the Alexandria, Egypt. Uni. of Alexandria, Egypt.

Børgesen, F. (1957). Some marine algae from Mauritius. Biol. Med. Dan. Vid., Selsk., 23:1-13.

Boyale, E. A.; Scatler, F. R. and Edmond, J. M. (1977). The distribution of dissolved copper in the Pacific. Earth Planet Sci. Letts., 37: 38-54.

Brewer, P. G. (1975). Minor elements in seawater. pp.415- 496 In: Chemical Oceanography. (Riley, J. P. and Skirrow, G. eds.). Academic Press, London.

Brook, R. R.; Presdy, B. J. and Kaplan, I. R. (1967). APDC-MIBK extraction system for determination of trace elements in saline waters by Atomic Absorption Spectrophotometry. Talanta, 14: 809-816.

Bruland, K. W. and Frankie, R. P. (1983). Mn, Ni, Cu, $\mathrm{Zn}$ and $\mathrm{Cd}$ in the Western North Atlantic. NATO Research Institute Conference "Trace metals in seawater". Erice, Italy, Mar.-Apr. 1981. Plenum Press, New York.

Buo-Olayan, A. H. and Subrahmanyam, M. N. V. (1996). Heavy metals in marine algae of the Kuwait Coast. Bull. Environ. Toxicol., 57: 816-825. 
Cranston, R. E. and Murray, J. W. (1978). Dissolved chromium species in seawater. Spring Meeting AGO, EOS, 59: 306 p.

Dawson, E.Y. (1962). New taxa of benthic green, brown and red algae. Beaudette Found., Santo Ynez, California.

Dean, J. G.; Bosqui. F. L. and Lanouette, V. H. (1972). Removing heavy metals from wastewater. Environ. Sci. Technol., 6: 518- 522.

Dowidar, N. M. and El-Nady, F. E. (1987). Distribution of some trace metals in the Mediterranean waters off the Nile Delta. Bull. Inst. Oceanogr. and Fish., ARE, 13 (2): 21- 27.

EL-Moselhy, Kh. M. (1993). Studies on the heavy metals level in some economic fishes in Suez Gulf. M.Sc. Thesis, Fac. Sci., Mansoura University.

El-Moselhy, Kh. M.; Diab, A. A.; Tolba, M. R. and Mahamadein, L. I. (1999). Levels of some heavy metals in coastal water, sediments and limpet Patella sp. from the northern part of the Gulf of Suez (Suez Bay). Egypt. J. Aquat. Bio. and Fish., 2 (2): 69-84.

El-Sarraf, W. M. (1995). Heavy metals in some marine algae from Alexandria, Egypt. Bull. Fac. Sci. Alexandria.Univ., 135, (2): 475-487.

Emara, H. I.; Shriadah, M. A.; Moustafa, T. H. and EL-Deek, M. S. (1995). Trace metals-nutrient salts relationship in coastal seawater of Alexandria. Proc. $2^{\text {nd }}$ Conf. MEDCOAST., Oct. 14-17, 1995, Tarragona, Spain, 3: 1457-1464.

Espinoza-Quinones, F. R.; Zacarkim, C. E.; Palacio S. M.; Obregon C. L.; Zenatti, D. C.; Galante, R. M.; Rossi, N.; Rossi, F. L.; Pereira, I. R. A.; Welter, R. A. and Rizzutto, M. A. (2005). Removal of heavy metal from polluted river water using aquatic macrophytes Salvinia sp Braz. J. Phys., 35: 3-9.

Folsom, T. R. and Young, D. R. (1965). Silver-110 and cobalt-60 in oceanic and coastal organisms. Nature, London, 206: 803-806.

Folsom, T. R.; Young, D. R.; Johonson, J. N. and Pillai, K. C. (1963). Manganese-54 and zinc 65 in coastal organisms of California. Nature. London, 200: 327-329.

Forstner, U. and Wittmann, G. T. W. (1981). Metal Pollution in the Aquatic Environment. Springer-Verlag, Berlin, 486 p.

Garrison, T. (2004). Oceanography: An Invitation to Marine Science (Case bound with Oceanography now and In future). 544 pp.

Goldberg, E. D. (1965). The oceans as chemical systems. pp. 3-25 In: The SeaIdeas and Observations on Progress in the Study of Seas. (M. N. Hill, E. D. Goldberg, C.D. Iselin and W. H. Munk, eds), Wiley, New York, USA. 
Hamed, M. A. (1996). Determination of some micro-elements in the aquatic ecosystems and their relation to the efficiency of aquatic life. Ph.D. Thesis, Fac. Sci., Mansoura University.

Harper, D. J. (1988). Distribution of $\mathrm{Cd}$ and $\mathrm{Pb}$ in the Thames Estuary. Mar. Chem., 33: 131-143.

Hester, R. E. and Harrison, R. M. (2000). Chemistry in the Marine Environment. 112 pp.

Jaasund, E. (1977). Marine algae in Tanzania. Bot. Mar., 20:509-520.

Jaleel, T.; Jaffar, M.; Ashraf, M. and Moazzam, M. (1993). Heavy metal concentrations in fish, shrimp, seaweed, sediment and water from Arabian Sea, Pakistan. Mar. Pollut. Bull., 26 (11): 644-647.

Jickells, T. D. and Knap, A. H. (1984). The distribution and geochemistry of some trace metals in the Bermuda coastal environment. Estuar. Coast. and Shelf Sci., 18: 245-165.

Koeppe, D. and Miller, R. (1970). Lead effects on corn mitochondrial respiration. Science, 167: 1376- 1377.

Langston, W. J. (1986). Metals in sediments and benthic organisms in Mersey Estuary. Estuar. Coast. Shelf Sci., 23: 239-249.

Li, A. C. and Chin, L. R. (1997). Characteristics of eolian dust over the Eastern China Seas. Chin. J. Oceanol. Limnol., 15 (2): 112- 177.

Magnusson, B. and Ramussun, L. (1982). Trace metal levels in coastal seawater. Investigation of Danish waters. Mar. Pollut. Bull., 13(3): 81-84.

Malea, P. and Haritonidis S. (2000). Use of the green alga Ulva rigida (C. Agardh) as an indicator species to reassess metal pollution in the Thermaikos Gulf, Greece, after 13 years. J. Appl.Phycol., 12: 169-176.

Malea, P.; Haritonidis, S. and Kevrekidis, T. (1995). Metal content of some green and brown seaweeds from Antikyra Gulf (Greece). Hydrobiol, 310: 19-31.

Moore, J. W. (1991). Inorganic contaminants of water research and monitoring priorities. Desanto, R. S. (ed). In: Springer Series, Environmental Management, Springer-Verlag., New York, USA.

Muse, J. O.; Tudino, M. B.; d'Huicque, L.; Troccoli, O. E. and Carducci, C. N., (1995). A survey of some trace elements in seaweeds from Patagonia, Argentina. Environ. Pollut., 87: 249-253.

Muse, J. O.; Stripiekis, J. D.; Fernandez, F. M.; d'Huicque, L.; Tudino, M. B.; Carducci, C. N. and Troccoli, O. E. (1999). Seaweeds in the assessment of heavy metal pollution in the Gulf San Jorge, Argentina. Environ. Pollut., 104: 315-322.

Park, J. and Plock, D. (1971). A role of zinc in the structural integrity of cytoplasmic ribosomes of Euglena gracilis. Plant. Physiol., Lancaster, 48: $150-155$. 
Phillips, D. J. H. (1977). The use of biological indicator organisms to monitor trace metal pollution in marine and estuarine environments- a review. Environ. Pollut., 13: 281-317.

Phillips, D. J. H. (1993). Macrophytes as biomonitors of trace metals. In Biomonitoring of Coastal Waters and Estuaries.(K. J. M. Kramer, ed.). CRC Press, Boca Raton, Florida, USA.

Preston, A; Jefferies, D. F.; Dutton, J. W. R.; Harvey, B. R. and Steele, A. K., (1972). British Isles coastal waters: The concentrations of selected heavy metals in seawater, Suspended matter and biological indicators - a pilot survey. Environ. Pollut., 3: 69-82.

Rai, U. N.; Sinha, S.; Tripathi, R. D. and Chandra, P. (1995). Zn and $\mathrm{Cu}$ concentrations in Ascophyllum nodosum after transplantation to an estuary contaminated with mine wastes. Ecological Engineering, 5:1-5.

Ray, G. C. and Ray, J. M. (2002). Coastal Marine Conservation. Academic Press, London, 288 pp.

Rebechini, H. and Zegers, P. (1972). Analysis of physiological and morphological effects of lead on the chloroplasts of water milfoil. In: A study of pollution in Illinois rivers. Illinois University, National Science Foundation, Grant GY - 9661.

Riley, J. P. and Skirrow, G. (1965). Chemical Oceanography. Academic Press, London, Vol. I and II, 411 p.

Seanko, G. N.; Koryakova, M. D.; Makienko, N. F. and Dobrosmysolva, I. G., (1976). Concentration of polyvalent metals by seaweeds in Vostok Bay, Sea of Japan. Mar. Biol., 34: 169-179.

Shiber, J. (1980). Trace metals with seasonal concentrations in coastal algae and molluscs from Ras Beirut, Lebanon. Hydrobiol., 69 (2): 147-162.

Sivalingam, P. M. (1978). Biodeposited trace metals and mineral content studies of some tropical marine algae. Bot. Mar., 21(1): 327-330.

Tomlinson, D. L.; Wilson, J. G.; Harris, C. R. and Jeffry, D. W., (1980). Problems in the assessment of heavy metal levels in estuaries and the formation of a pollution index. Helgolander Meeresunters, 33: 566-575.

Wahbeh, M. I. (1985). Concentrations of zinc, manganese, copper, magnesium and iron in ten species of algae and seawater from Aqaba, Jordan. Mar. Environ. Res., 16: 95-102.

Waldichut, M. (1974). Some biological concerns in heavy metal pollution. pp. 154 In: Pollution and Physiology of Marine Organisms, (eds. Vernberg F. $J$ and Vernberg W. B.), Academic Press, New York, USA

Zamuda, C. D. and Sunda, W. G. (1982). Bioavailability of dissolved copper to the American Oyster Crassostrea virginica. I. Importance of chemical speciation. Mar. Biol., 66: 77-82. 


\section{مستويات المعادن الثقيلة فى الطحالب البحرية الشائعة بخليج السويس

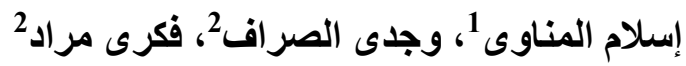

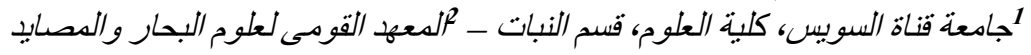

قيست مستويات معادن الكدميو و الكولبت و الكروم و النحاس و المنجنيز و الحديد و الرصاص و والنيكل و الزنكلك

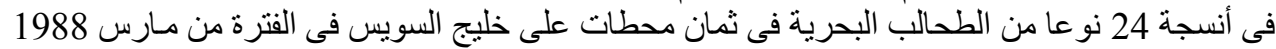

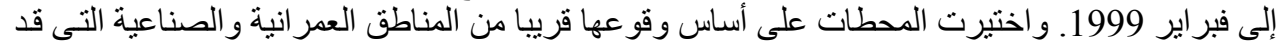

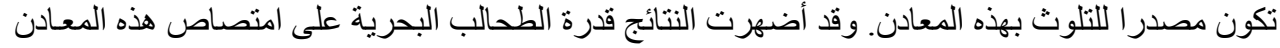

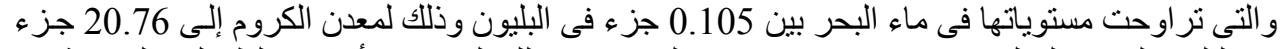

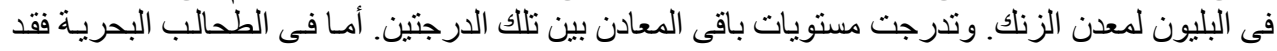

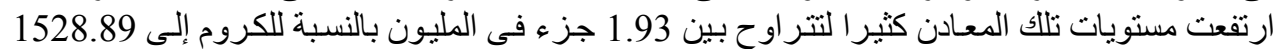

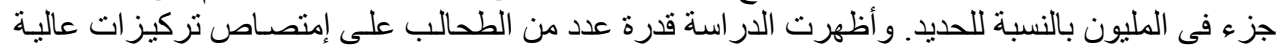

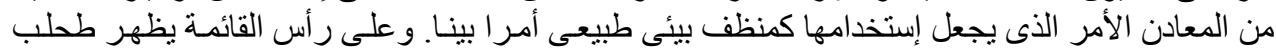

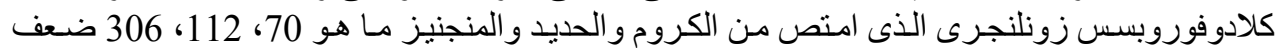

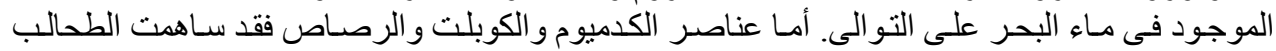

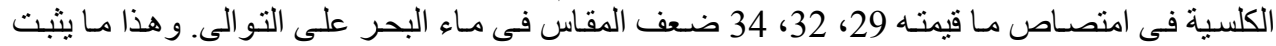
فاعلية هذه الطحالب كمنظف بيئى للملوثات. 